\title{
EFFECTS OF WORD PROCESSING ON TEXT REVISION
}

\author{
Annie Piolat \\ Centre de Recherche PsyCLE, Université de Provence, \\ 29 Av. Schuman, F-13621 Aix Cedex, France
}

\begin{abstract}
Revising is an evaluating and editing process that is an essential part of text production. Is text revising facilitated by the use of word processors? After examining the related research, it is difficult to conclude with certainty that the use of word processors is always effective in improving writers' revising skills, or that their use necessarily leads to the production of higher quality texts. Their effectiveness depends on a large number of parameters (computer equipment, writing skills, task execution conditions) which psychologists are now starting to measure.
\end{abstract}

\section{Introduction}

The purpose of this paper is to assess the effectiveness of word processors as writing aids by reviewing the related literature published within the last ten years. This review should allow us to answer the following question: is text revision, and thus text improvement, clearly facilitated by the use of word processors?

Studies on text revision have shown that when experienced writers revise, they are able to improve not only the surface aspects of their texts, but also the meaning. Inexperienced writers, on the other hand, make mainly surface corrections, generally limited to the word level (Butler-Nalin, 1984; Bridwell, 1980; Daiute, 1981; Fayol \& Gombert, 1987; Faigley \& Witte, 1984; Fitzgerald, 1987; Piolat, 1988; Piolat \& Roussey, in press; Nold, 1981; Scardamalia \& Bereiter, 1983; Witte, 1985). An important goal is thus to help novices and non-experts become more efficient writers. Indeed, revising is an editing process that is essential to text production. As a control process, revision allows writers to regulate their activity and reach their writing goals (Flower, Hayes, Carey, Schriver \& Stratman, 1986; Scardamalia \& Bereiter, 1987). By encouraging writers to use word processors, psychologists and educational specialists hope to increase the extent of this kind of control. Comparison of the many research findings in this field is a tricky endeavour. Works of substantial methodological diversity must be compared to each other (e.g. introspective reports: McKenzie, 1984; case studies: Bridwell, Sirc \& Brooke, 1985; instructional experience accounts: Rodriques, 1985; informal exploration: Harris, 1985; surveys: Schwartz, 1982; experimental studies; Kurth, 1987). The experimental studies alone have also 
employed highly diverse procedures (i.e. with or without control groups, variable experimentation period, number of papers ... ). Faced with this difficulty, already brought out in the reviews by Barker (1987), Hawisher (1987), and Kurth (1987), Bangert-Drowns (1989) abandoned any attempt at meta-analysis.

Despite this diversity, we can nevertheless group similar information together and examine the various studies to point out gaps, differences in perspective, goals and ways of approaching the issue of text revision and the effects of new technology on the revision process.

Word processors have multiple uses in the business world (networking, electronic mail, long-distance conferences ... ; see Halpern \& Liggett, 1984; Odell $\&$ Goswami, 1985). The use of the computer and word processors in educational settings has been facilitated (especially in the United States) by a large volume of explanatory literature (Collins \& Sommers, 1985; Zinsser, 1983). Daiute's book is a perfect example of this. It provides many technical details about the characteristics of computers and word processors. Diaute also discusses the instructional virtues of this tool for three age groups (very young, 9-13 year olds, adolescents), taking into account their respective abilities to plan, translate into text form, and revise. The specificity of this writing medium-i.e. the fact that the composition phase is separate from the printing phase-distinguishes it from other production modes (pencil and paper, typewriter), as analysed by Hilligos (1983). As for text revision, Daiute (1985) and Selfe (1985) clearly describe the different functions available on word processors for transforming the product in the course of composition (delete, cut, paste, search, replace, move a block of text, etc.).

The present study will approach the use of these functions and their effects on the improvement of the final text. The following analysis of their impact as potential technological aids to revision will be dealt with both observational and experimental studies, and will only concern word processing perse, and not the assistance programs developed within the past ten years to accompany word processors, which include text analysers that examine the produced text (spelling checkers, sentence length verifiers, etc.) and prompting programs that encourage self-questioning by the writer.

\section{Observational Studies of Word Processor's Effects}

The way in which psychologists and teachers view and measure the effects of word processing on essay revision is contingent upon their conception of the revision process.

Process models (Bridwell, 1980; Frederiksen \& Dominic, 1981; Molitor, 1989), and in particular Scardamalia \& Bereiter's (1985) 'Compare-Diagnose-Operate' model, have shown that revising is a decisional process that is much more important than previously considered by Flower \& Hayes (1981), who reduced revision to 'reading-writing'. Accordingly, Flower, Hayes, Carey, Schriver \& Stratman (1986) described sequences of subprocesses (task definition, evaluation aimed at problem detection or diagnosis, strategy used to rewrite or revise) and the kinds of knowledge required (means-ends table, etc.). Along with these models, the representation and study of text improvement -strategies' has also 
been developed within the past decade (for a review, see Piolat \& Roussey, in press).

To illustrate this point, we might base our review on the four questions Hawisher (1986) attempted to answer in her research on the potential role of word processors:

(1) 'Do students revise more extensively with word processors than with a pencil or a typewriter?'

(2) 'Are the kinds of revisions students make with a word processor different from those made with a pencil or a typewriter?'

(3) 'Is there a relationship between the extent to which students revise and the quality of their essays?'

(4) 'Do students revise more effectively with word processors than with other means (pencil, typewriter)?' (p. 8)

The first two questions clearly reflect the predominant conception of the early 1980s that writers do little revising (Bartlett, 1982; Humes, 1983; Monahan, 1982; Sommers, 1980). However, although revising is indeed essential to becoming an expert writer, only experienced writers make numerous corrections and control both the surface aspects and the deeper levels of their texts. (For a typology of revisions, see Faigley \& Witte, 1981 and 1984, whose classification of text corrections has often been borrowed in studies on the effects of word processing). In addition, since researchers with the prevailing conception of the early 1980s generally measure changes in the product rather than analyse the progression of the writing process, revision strategies have been defined in terms of the amount of change they trigger at the different linguistic levels of the text.

In this framework, word processors appear to be educational tools that are highly suited to promoting the most efficient strategies (high-level revision) due to their ergonomical qualities: no recopying, ease with which deleting, adding, and moving can be performed on letters and blocks of sentences. The results of research conducted in this area can be classified by the answers they gave to Hawisher's (1986) questions:

Question 1 (amount of revision). The following authors responded affirmatively: (Barber, 1984; Bean, 1983; Bickel, 1985; Bradley, 1982; Bridwell, Nancarrow \& Ross, 1984; Bridwell \& Duin, 1985; Bridwell, Sirc \& Brooke, 1985; Card, Robert \& Keenan, 1985; Castner, 1983; Collier, 1983; Daiute, 1982, 1983, 1984; Kleiman \& Humphrey, 1982; Hennings, 1981; Lindemann \& Willert, 1985; McKenzie, 1984; Monahan, 1982; Moran, 1983; Newman, 1984; Piper, 1983; Schwartz, 1982; Schwartz, 1984; Shostak, 1982; Whitney, 1983). Only Harris (1985) responded negatively.

Question 2 (kinds of corrections). The following authors responded affirmatively: Bean, 1983; Bickel, 1985; Bridwell \& Duin, 1985; Bridwell, Sirc \& Brooke, 1985; Castner, 1983; Daiute, 1982, 1983; Hunter, 1983; Kleiman \& Humphrey, 1982; Lindemann \& Willert, 1985; McKenzie, 1984; Monahan, 1982; Newman, 1984; Nold, 1981; Pearson \& Wilkinson, 1986; Rodrigues, 1985; Schwartz, 1982; Suhol, 1985. The following authors responded negatively: Card, Robert \& Keenan, 1985; 
Carlson, 1983; Collier, 1983; Daiute, 1986; Gould, 1981; Harris, 1985; Hult, 1985; Morocco \& Neuman, 1986; Womble, 1984.

Based on this distribution of authors, the following conclusion can be drawn: when using a word processor, writers revise more, but not necessarily at the 'deeper' levels of their texts.

Hawisher's third and fourth questions (1986) on the effectiveness of revisions and the quality of the produced texts should be approached with caution, and are aimed at slowing down certain researchers who have been overly enthusiastic about the benefits of word processing. Responses to these two questions were as follows:

Question 3 and 4 (revision effectiveness and text quality). The following authors responded affirmatively: Bean, 1983; Bickel, 1985; Halpern \& Liggett, 1984; Kurth, 1987; Lindemann \& Willert, 1985; McKenzie, 1984; Monahan, 1982; Pearson \& Wilkinson, 1986; Schwartz, 1982. The following authors responded negatively: Card, Robert \& Keenan, 1985; Carlson, 1983; Collier, 1983; Daiute, 1984, 1986; Hawisher, 1986; Rodrigues, 1985; Woodruff, Bereiter \& Scardamalia, 1981-82; Woodruff, Lindsay, Bryson \& Joram, 1986.

In the light of such findings, a clear stand on whether or not word processors are beneficial or detrimental to text improvement cannot legitimately be taken. At this point, the conclusions drawn by certain authors, many of whom had not analysed the quality of the corrected text (Bickel, 1985; Castner, 1983; Lindemann \& Willert, 1985; Loheyde, 1984; McKenzie, 1984; Papert, 1980; Watt, 1983) appear overly enthusiastic. The caution of other authors, warned by their results, is quite understandable (Bridwell, Nancarrow \& Ross, 1984; Case, 1985; Collier, 1983; Harris, 1985; Morocco \& Neuman, 1986; Pearson \& Wilkinson, 1986; Sommers, 1985).

Thus, the researchers working after this 1980-85 period, whose goal had been to obtain an increase in the number of high-level corrections, became used to more experimental approaches. Since word processors had not instantaneously led to the desired effects, they were to be viewed as a tool to assist in production, a complex and cognitively costly activity. The conditions favouring their most effective use were to become part of current research goals by the mid 1980s. Both the more peripheral aspects of revising with a word processor, such as typewriting and text editing skills, as well as the more central aspects like the writer's skill and ability to adapt to the constraints of the revision task, began to be studied in greater detail, each in its own right.

The research summarised below has shown that in order to assess the effects of word processing on revising ability, various factors affecting the conditions under which the tool is used must be taken into account. The following points will be examined: the computer equipment used (type, screen, keyboard features, program etc.), the writer's skill (mastery of the text editor, revising expertise etc.), and the conditions of task execution required of the writer (number of sessions for rough drafts, type of prompting, etc.).

This investigation should allow us to go from the simple measure of the number of corrections to the analysis of how the revising activity is transformed through the use of a word processor. 


\section{Principal Experimental Factors}

\section{Computer equipment}

Due to the obvious lack of space, it is impossible to give a detailed account here of the role of the computer equipment used (for a review, see Piolat, 1990). However, the ergonomical analysis of how the technical characteristics of the device interact with the execution modes of the revising activity must at least approach problems related to the size of the screen (Harris, 1985; Ross \& Bridwell, 1984), reading on the screen (Gould \& Grischkowsy, 1984; Haas \& Hayes, 1986), information input devices (Haller, Mustchler \& Voss, 1985), types of software (Bradley, 1982), and accessibility of editing functions (Card, Moran \& Newell, 1983; Card, Robert \& Keenan, 1985; Pavard, 1985; Pynte, 1988).

The impact of the computer equipment used can be illustrated by the Lutz research (1987): approximately ten professional or experienced writers were asked to improve some texts (press reviews) by either modifying their own texts ('revise') or those of other writers ('edit'). Four conditions were analysed: (1) composing and revising on a computer, (2) editing on a computer, (3) composing and revising with pencil and paper, and,(4) editing with pencil and paper. In those conditions using computers, all modifications had to be made on the screen, even though a hard copy was available (all operations done on the screen and keyboard were recorded). In those conditions using pencil and paper, the corrections were made with a pencil of a different colour.

The main results were as follows:

- There was no difference in operations done between the revising and editing conditions. The latter was found to be just as complex as the former, especially when done on a computer.

- Use of a word processor, as compared to pencil and paper, led to the production of shorter texts, made up of shorter sentences that took longer to generate. The changes made were indeed more numerous and extended over a greater number of sessions.

-Writers moved around more in the text (shifts backwards or forwards with respect to the current location of the cursor or pencil) with the word processor than with pencil/paper. However, these moves covered a shorter distance (number of lines between modifications in the text) with the word processor.

- Most modifications made with the word processor were surface corrections. In comparison to pencil/paper, the number of transformations decreased considerably as linguistic unit size increased (word, phrase, clause, sentence, paragraph). This decrease was not as large for pencil and paper.

Thus, revising with the aid of a computer involves a greater number of corrections of a small size made on short portions of text. The subjects' answers to subsequent questioning showed that using a computer is judged to be easy and leads to greater creativity by allowing ideas to be recorded as soon as they come to the writer's mind. Subjects also felt it provides incentive to revise. However, in spite of these apparent advantages, writers are faced with two disadvantages when managing information on a word processor: (1) It encourages them to 'play 
around' as they explore their texts with the cursor and search keys, which they never really use, and (2) it focuses their attention on small sized sections of text as they appear on the screen, which leads them to modify mainly the surface aspects of the text.

Thus, for this author, it is essential to encourage users to work from printed copies of their texts so that larger sections of text such as paragraphs can be reordered and reorganised. This is very clearly true for the editing task, where writers do a much better job on paper than on a word processor.

The results of this study (in conjunction with those of other research: see Piolat, 1990; Morton et al., 1989; Pontecorvo \& Paoletti, 1989) allow us to conclude that the use of computer equipment (in the broadest sense) has an impact on the revising procedures used by writers. Regardless of certain methodological flaws in some of the studies (i.e. small numbers of subjects, no control group, lack of statistical tests, etc.), the importance of man-machine interaction during a text improvement task has nevertheless been demonstrated.

\section{Writing skills}

In addition to computer equipment effects, the varying levels of writing skills can also influence the way in which a word processor is used to make revisions. The term 'skill' is used here to refer to the wide range of knowledge and knowhow involved in writing a text. Writing is a complex problem-solving activity that requires the writer to overcome a certain number of difficulties such as how to manage knowledge and goals, and how to translate into text form (spelling, word choice, syntax, etc.; Scardamalia \& Bereiter, 1987; Flower \& Hayes, 1981). The development of expertise presupposes both the automation of certain aspects of the activity and the powerful metacognitive control that conditions the execution of substantial deep-level revision (Bryson, Bereiter, Scardamalia \& Joram, in press). One question that might be raised is whether the only effect of word processing is to relieve the user of the physical constraints of writing by hand (Daiute, 1986), or whether it also permits non-expert writers to improve the cognitive aspects of their limited revising capabilities. For the research reviewed here, two aspects of the writer's skill will be assessed: (1) mastery of typewriting and editing functions, and (2) mastery of the word processor. It is worth noticing that researchers do not analyse the effects of the writer's expertise in the content domain and the writer's purpose in writing. Studies were mainly conducted in school environments; the topic of the composition belongs to the usual teaching programme, the teacher serving as the audience.

Typing skills appear to be poorly developed in young writers. Later, Branganca $\&$ Rukavina noted that very few children age 6,8 and even 11 years say they type with both hands using all fingers. The most skilled limit their use of editing functions to deleting character-by-character. After a learning session teaching the use of the keyboard, Britten (1988) concluded that typing ability may affect the execution of revisions at different levels. But other authors have found a decrease in the number of surface modifications made by writers in the course of text elaboration, due to an improvement in typing ability (decrease in number of 
typographical and manipulation errors), but without a genuine increase in the writers' ability to revise (Bridwell, Sirc \& Brooke, 1985).

The study by Joram, Woodruff, Lindsay \& Bryson (1989) has again shown that young adolescents (age 13) are poor typers (average typing speed: eight words per minute) and are especially unskilled in the use of editing functions. These authors hypothesise that limited typing and editing skills are the reason why writers more often correct the surface aspects of their texts than the meaning. On the basis of the results obtained from an editing task and questionnaire, they concluded that their students were poor at text editing and typing, and seemed to use this expensive tool not more than a typewriter. Indeed, these subjects only used the delete and insert commands, hardly ever executing any of the other commands learned such as cut, paste, and search, which would allow them to correct the meaning of their texts. According to these authors, poor editing ability may also interfere with the composition process, causing students to prefer using the computer only to type the final draft. Thus, making sure that writers possess the necessary typing, and above all, text editing skills would allow researchers to avoid a faulty interpretation of the increase in number of corrections, which are generally made at the surface level. Moreover, more word processors with simplified commands should be developed. In that direction, the ICON system (Ontario Approved Educational Computer) seems to be an efficient tool.

Differences in performance between intermediate level writers and more expert writers, which have clearly been found in studies on pencil-and-paper revising (Hayes et al., 1987; Fitzgerald, 1987), have also been found repeatedly in experiments on word processing. For drafts written by highly disadvantaged children and very mediocre writers, a few studies have shown that using the computer leads to an increase in the number of corrections (essentially surface-level), implying that word processors serve as an aid to transcription (Kleiman \& Humphrey, 1982; Cameron \& Kress, 1984; Collier, 1983; Woodruff, Bereiter \& Scardamalia, 1982). However, researchers who have the expectation that word processors will help poor writers have often been disappointed. Thanks to the verbal protocol method, Woodruff, Lindsay, Bryson \& Joram (1986) were able to determine which processes students of differing levels of writing skill focus their attention upon as they revise with a word processor (Planning, Generating, Editing, Environmental concerns, Evaluations). Only the more skilled students take advantage of the computer tool to make more high-level corrections. The less skilled ones focus only on surface modifications, and therefore do not activate cognitive resources to control the macrostructural levels of their texts. Thus, the writing skill level of the student determines the type of assistance the computer can administer.

As it stands, word processors do not necessarily provide effective assistance. Authors like Joram, Woodruff, Bryson \& Lindsay (1989) hypothesise from the results obtained by Freedman et al. (1988), for example, and also by Hawisher (1987), that frequent revision with a word processor may distract writers from the highly-processes of composing. This distraction is associated with decreases rather than increases in the rated quality of texts. These authors think that a distinction must be made between the potential of word processors to enhance 
revision, and the actual practices students engage in when they compose with word processors. Thus, instructional methods should be set up in order to control the direction of the student's attention towards a given linguistic level or a given revising strategy, depending on the writing stage he/she is engaged in. These aspects of revising are discussed below with regard to the conditions of task execution.

\section{Task execution conditions}

Two aspects of the task execution conditions must be considered here: (a) text elaboration mode, as each new draft is generated session by session, and (b) the task execution requirements imposed by the experimenter either in the instructions or by means of a pre-task.

All attitude questionnaires (or informal interviews) on writing with a word processor have indicated the same thing since the very first studies on the role of word pfocessing: writers enjoy using a word processor because they can settle down immediately to the task, are captivated by the screen, and can provide clear documents to other people (Bradley, 1982; Bridwell, Sirc \& Brooke, 1985; Collier, 1983; Barker, 1987; Dalton \& Hannafin, 1987; Meyers \& Tilly, 1986; Wresch, 1984). The study by Joram, Woodruff, Lindsay \& Bryson (in press) qualifies this statement, however: only half of the adolescents interviewed (age 13) said they preferred word processing to pencil and paper.

Moreover, the responses to such questionnaires have clearly indicated that students, and even experienced adult writers, prefer composing the first draft with pencil and paper and then using a word processor to revise the final draft after having pinpointed the problems on the printed copy (Bridwell-Bowles, Johnson \& Brehe; 1987; Bridwell, Sirc \& Brooke, 1985; Joram, Woodruff, Bryson $\&$ Lindsay, in press; Teles, in press; Woodruff et al., 1986). The explanations given for this by interviewed subjects have mostly concerned the actualisation mode of the writing processes. According to these subjects, management of the first draft, when ideas are still unorganised and spread across several pages is hindered by the insufficient size of computer screens which only show small portions of text. Consequently, corrections are easier to make with pencil and paper. On the other hand, surface corrections, which are usually made during the final composition phase, are easier on a word processor.

Writers thus have different attitudes about the utility of word processors, depending on what stage of the writing process they are engaged in. Many have no doubt realised that their poor mastery of the text editor interferes with the planning and revising required to write the first draft.

It is as if poor mastery of the computer somehow works against the necessary recurrent processes that intervene throughout the composition (planning, translation, revision). Conventional word processor functions (cut, paste, delete, search, insert), even when used skillfully by writers, do not seem to be sufficient for simultaneous planning and revising (where revising is understood to be not just the 'transformation' of the translation, but also as a revision of plans; see Witte, 1985). Ergonomists have thus devised idea-organising programs and pre-writing 
programs in addition to word processors. Pre-writing programs must be nonlinear and non-hierarchical, but must simulate on the screen the use of several sheets of paper, through the use of windows, for example (Bangert-Drowns \& Kozma, 1989; Bisseret, 1987; Friedman, 1987; Strickland, 1985). Word processors seem to incite still inexperienced writers to write on a session-by-session basis following the classic conception of the stages of writing, namely (a) find ideas and translate them into a rough draft in the pencil-and-paper medium, (b) revise the rough draft to improve the text as a whole, again, on paper, and finally (c) use a word processor (and its accompanying writing aid programs such as spelling checkers) to polish up the text and eliminate remaining surface errors. Because of this, the use of a word processor may have 'regressive', 'interrelated' effects upon the writing procedures of learners, because the notion of a chronological order for the 'pre-writing, writing, revising' processes does not correspond to the strategies of expert writers.

In order to improve the word-processing performance of poor writers, two approaches seem possible: (1) add computerised aids to teach these writers how to effectively use this tool (see Piolat \& Blaye, 1991; Frase, Kiefer, Smith \& Fox, 1985; Frase, 1984; Kozma, 1989; McClurg \& Kasakow, 1989), and (2) guide the user as he/she composes on the word processor by providing instructional assistance.

This second approach could consist of encouraging novice or average writers to compose and revise by modelling their activity after the most common behaviour manifested by experts. Modelling of this sort is induced by an external individual who provides instructional intervention. The studies conducted by scientists at the O.I.S.E. (Center for Applied Cognitive Science) have provided evidence of some of the contributions and limitations of this type of intervention.

Accordingly, the goals set by Bryson, Lindsay, Joram \& Woodruff (1986; see also Joram, Woodruff, Bryson \& Lindsay, in press) were:

(a) to regulate the surplus editing activity done by nonexpert writers during the rough draft stage by momentarily preventing them from correcting the surface level of their texts (see 'no-edit composing' versus 'free-edit composing', studied by Joram, 1986);

(b) to direct the revision towards mastery of the quality of the text as a whole by requiring writers to remove or add a sentence, or to move two sentences they choose themselves ('direct revising' versus 'spontaneous revising');

(c) find out whether these instructions are more effective when writers use pencil and paper or a word processor.

Their results were rather disappointing. They suggest that the provision of a word processor did not benefit either the writing processes (as reflected in the think aloud protocols), or the product ratings of writers. Even more disappointing, average writers seemed totally unable to take similar advantage of the constrained composing conditions. The more expert students, however, managed to take advantage of the opportunity provided by one of the two tasks. With the 'noedit' instructions, they started focusing during the first draft on deeper text levels. The 'direct revising' technique was found to have a more beneficial effect on the 
quality of texts when it was applied using a word processor than when 'penciland-paper and typewriter' were used. The 'direct revising' instructions do not have a beneficial effect on the quality of the texts produced by more skillful writers. The 'no-edit' instructions only turn out to be effective with skillful students when they know they can use a word processor later on to eliminate surface errors from their text, and will not have to do so by hand. Given these results, it seems difficult to call these tasks 'implicitly facilitating'. The authors conclude, moreover, that instructing immature writers to imitate the outward behaviour of experts was clearly an unsuccessful approach.

Roussey (1991) found that a highly simplified word processor had efficient and beneficial effects on the revising strategies of 10-year-olds and adults correcting a short experimental text. The 'implicitly facilitating' procedure in this case was not restricted, as it was in prior research, to simple verbal instructions given to writers before the rough draft. In accordance with the high performance of expert writers, some of the revisers were led to execute a series of moves on the screen with clearly defined constraints vis-à-vis the goal to be attained. The other subjects were asked to read several texts containing various deviations from the text schema, as explained by metalinguistic comments. Performance on the revising task following this training (correction of local and global errors inserted experimentally in a text) was quantified in the form of (a) the distance between the produced text and the expected text, and (b) the succession of correction-sequencing procedures used.

The results showed that regardless of the nature of the modelling done during the pre-test, the great majority of the subjects, even the non-expert ones, benefitted from the training, some managing to arrive at the correct version of the text, and others managing to employ an expert correction-ordering procedure.

However, the pre-task that focused on superstructure knowledge was the one that led to the best results (both in the produced text and in the complex correction-sequencing strategy used). The non-expert children were able to better control the step-by-step processes involved in the screen revising task when they had first benefitted from the modelling, which aided them in establishing the goal they were to reach (knowledge of the text schema and appropriate definition of the task).

The results of these studies allow us to infer that word processors can only help nonexpert writers to progress if the use of the tool is based on a method that efficiently structures the revising task. The main features of such a method (nature of the knowledge and know-how required to use it) must be adapted to the nonexpert competency level and to the obstacles nonexperts encounter. It is ineffective to attempt to use verbal instructions or pre-tasks to `force' novice writers to attain the revising behaviour of experts on a word processor. We must give them procedural means and cognitive support that will allow them to reach that level, as we continue to explore the nature of the cognitive difficulties confronting them. 


\section{Summary and Discussion}

The main objective of the initial research reviewed here was to provide an a

posteriori account of the types of modifications (surface changes versus text-base changes) writers make to their rough drafts when they use word processors, with the underlying idea that the greater the number of modifications, the better. Findings have been disappointing: corrections were found for the most part to be superficial, and users did not take full advantage of the transformation functions offered by the computer. The greatest benefits seem to be motivational: regardless of their degree of expertise, users spend more time writing.

Following this initial research stage, there was a change in perspective, both in the study of text revising and in research on the effects of word processing upon the user's ability to improve a text as it is being composed. In order to understand how writers actually proceed when revising, psychologists indeed could not settle for simply analysing the result of the writer's activity, i.e. the number and nature of the corrections made, and their impact on the quality of the final text. The constraints that may modulate the conditions under which the revising task is executed had to be further specified. Accordingly, a second more experimental research perspective replaced the first.

The role of two major types of constraints was then studied: the first involves the physical characteristics of the word processing system (screen size, data input devices, ... ) and the second deals with the subject's abilities (typing skills, writing expertise, ....).

Indeed, certain 'pragmatic' constraints that clearly condition 'man-machine' interaction modes (Card, Robert \& Keenan, 1985; Pavard, 1985) are inherent in word processing systems. These constraints can be advantageous or detrimental in comparison to the constraints of writing by hand. Suhol (1985), for example, stressed that the benefits of using a word processor lie in the 'additive' way in which a writer can write and rewrite several solutions on the screen, only to choose the best one afterwards, and erase the others without having to recopy.

As for the writer's abilities, the most problematic finding (also a frequent one in the research reviewed here) is that the difference in performance in text composition between novice or average writers and expert or professional writers becomes even greater when a word processor is used for revision (for example: Woodruff, Lindsay, Bryson \& Joram, 1986).

Thus, in an attempt to improve the mediocre performance of poor users, authors began to focus their attention on developing instructional guidance or pre-tasks to aid readers in modelling their behaviour after that of expert writers using a word processor. Due to the limited number of studies conducted on this subject, it is still too soon to make any statements about the necessary features of such modelling procedures.

The above observations point out the lack of sufficient findings in this domain. We would like to emphasise that one of the primary objectives in any proposed research perspective should be to better understand the step-by-step procedures followed by writers as they transform a rough draft, with or without a word processor. The process models proposed by Scardamalia \& Bereiter (1983) and 
by Hayes, Flower, Schriver, Stratman \& Carey (1987) provide a highly detailed account of the processes carried out by writers to make a correction, but only one correction. Yet to improve a text, writers must successively make a series of corrections, while checking to see that each one is compatible with the others, often located at different linguistic levels. If text revision is considered to be a problem-solving activity, then our approach should be to determine how writers arrive at a 'completed' text, a final solution, through the scheduling of many corrections.

In order to study the correction-sequencing strategies used by writers to correct micro- and macrostructural errors inserted into short texts, Roussey, Piolat \& Guercin (1989) set up highly limited revising conditions (in comparison to normal word processing conditions). The subjects' performance was compared to efficient and economical solving strategies. The 10-year-olds were found not to use the same strategy as the adults to improve a narrative text. Unlike the adults, the children were unable simultaneously to focus on both of the involved linguistic levels to find a step-by-step solution to the problems encountered on the screen. They needed at least two sequential passes through the text to correct it, using a 'local-then-global' revision strategy. This study has shown that the sequencing of revising operations indeed constitutes a cognitive problem.

To understand how writers improve texts as a whole, the execution of revising tasks must be studied on-line, whether the revision is done on a word processor or by hand. The following question thus opens up a new line of research: does using a word processor modify the correction-sequencing procedures used by writers in an economical and facilitating fashion? This problem has not been approached per se since it involves overcoming three types of obstacles. Not only must the sequence of operations carried out on paper or on a computer screen and keyboard be recorded, but there must also be an adequate methodology available for analysing the resulting sequences statistically. In addition, since we cannot settle for experimental 'observation' alone, the modelling of the performance of writers is also indispensable.

Bridwell \& Duin (1985), Bridwell et al. (1984, 1985), and Bridwell, Johnson $\&$ Brehe (1987), for example, used a highly sophisticated on-line method to record the operations carried out by writers. Even more, through the use of video techniques, these authors were able to reproduce the step-by-step linguistic transformations done on the screen by writers. However, the large number of data collected were not dealt with sequentially, but quantitatively (number and type of corrections). The actual revising procedures employed on the word processor were only inferred, mostly on the basis of information obtained via interviews with the writers, not a fully satisfactory method. Handling such a large quantity of information is undeniably very complex. It requires a methodological tool allowing for the simultaneous coding of both the nature of the operations performed and their order of execution, after which the sequentially coded structures thus obtained can be compared. The 'time series' tool appears to be suitable for such coding and comparison (Guercin, Roussey \& Piolat, 1990). Finally, it should also be noted that unless the revising task is simplified and limited, unless a priori models of how the task is performed are defined, the researcher is confronted with vast quantities of data whose sequential interrelationships cannot be understood. 
Thus, despite its history extending over a ten-year period, the study of whether and how word processing can improve writing still appears to be walking on rough ground. Any claims about its beneficial or detrimental effects, especially for novice or average writers, cannot be made without a great deal of risk. Over and above just a simple analysis, we must discover through experimentation whether word processing technology actually performs the functions (co-piloting, problem structuring, lightening the cognitive load, etc. (Daiute, 1989)) that should be ensured by what Sharples \& O'Malley (1989) call a 'writer's assistant' capable of favouring more mature and thoughtful writing.

\section{References}

Bangert-Drowns, R. L. and Kozma, R. (1989) Assessing the design of instructional software. Journal of Research on Computing in Education.

Bangert-Drowns, R. S. (1989) Research on wordprocessing and writing instruction. Paper presented at the annual meeting of the American Educational Research Association, San Francisco, CA, March.

Barber, B. (1984) Creating BYTES of language. Language A rts 59, 472-75.

Barker, T. T. (1987) Studies in word processing and writing. Computers in the School 4(1), $109-21$.

Bartlett, E. J. (1982) Learning to revise: Some component process. In M. Nystrand (ed.) What Writers Know (pp. 345-63). New York: Academic Press.

Bean, H. C. (1983) Computerized word-processing as an aid to revision. College Composition and Communication 34, 146-8.

Bickel, L. L. (1985) Word processing and the integration of reading and writing instruction. In J. L. Collins and E. A. Sommers (eds) Writing On-Line: Using Computers in the Teaching of Writing (pp. 39-45). Upper Montclair, NJ: Boynton \& Cook Publishers.

Bisseret, A. (1987) Towards computer-aided text production. Document ronéoté INRIA, Mai.

Bradley, V. N. (1982) Improving students' writing with microcomputers. Language A rts $59,732-43$

Bridwell, L. S. (1980) Revising strategies in twelfth grade students' transactional writing. Research in the Teaching of English 14, 197-222.

Bridwell, L. S. and Duin, A. (1985) Looking in-depth at writers: Computers as writing medium and research tool. In J. L. Collins and E. A. Sommers (eds) Writing OnLine: Using Computers in the Teaching of Writing (pp. 115-21). Upper Montclair, NJ: Boynton \& Cook Publishers.

Bridwell, L. S., Nancarrow, P. R. and Ross, D. (1984) The writing process and the writing machine: Current research on word processors relevant to the teaching of composition. In R. Beach and L. S. Bridwell (eds) New Direction in Composition Research (pp. 381-98): New York, NJ: The Guilford Press.

Bridwell, L. S., Sirc, G. and Brooke, R. (1985) Revising and computing: Case studies of student writers. In S. W. Freedman (ed.) The Acquisition of Written Language: Response and Revision (pp. 172-94). Norwood, NJ: Ablex.

Bridwell-Bowles, L. S., Johnson, P. and Brehe, S. (1987) Computers and composing: Case studies of experienced writers. In A. Matsuhashi (ed.) Writing in Real Time: Modelling Production Processes (pp. 81-107). New York: Longman.

Britten, R. (1988) The effects of instruction on keyboardings skills in grade 2. Educational Technology April, 34-7.

Bryson, M. Bereiter, C., Scardamalia, M. and Joram, E. (in press). Going beyond the problem solving in expert and novice writers. In R. J. Sternberg and P. Frensch (eds) Complex Problem Solving. Hillsdale, NJ: Laurence Erlbaum.

Bryson, M., Lindsay, P. H., Joram, E. and Woodruff, E. (1986) Augmented word- 
processing: The influence of task characteristics and mode production on writers' cognitions. Paper presented at the Annual Meeting of the American Educational Research Association. San Francisco, California, April.

Butler-Nalin, K. (1984) Revision patterns in students' writing. In A. N. Applebee (ed.) Contexts for Learning to Write: Studies for Secondary School Instruction (pp. 121-215). Norwood, New Jersey: Ablex.

Cameron, J. and Kress, F. (1984) Word processing and the learning disabled high school student. ECCO Output 5(2), 30-1.

Card, S. K., Moran, T. P. and Newell, A. (1983) The Psychology of Human-Computer Interaction. Hillsdale, NJ: Lawrence Erlbaum.

Card, S. K., Robert, J. M. and Keenan L. N. (1985) On-line composition of text. In B. Shackel (ed.) INTERA CT '84: First Conference of Human-Computer Interaction (pp. 51-6). Amsterdam, North-Holland: Elsevier Science Publishers B.V..

Carlson, P. A. (1983) Computers and the composing process: Some observations and speculations. In S. Burton (ed.) Sixth International Conference on Computers and the Humanities (pp. 70-8). Rockville, ND.

Case, D. (1985) Processing professorial words: Personal computers and the writing habits of university professors. College Composition and Communication 36(3), 317-22.

Castner, B. A. (1983) Composition and literature: Learning to write with the computer terminals. In S. Burton (ed.) Sixth International Conference on Computers and the Humanities (pp. 79-82). Rockville, ND.

Collier, R. M. (1983) The word processor and revision strategies. College Composition and Communication 34, 149-55.

Collins, J. L. and Sommers, E. A. (1985) Writing On-Line: Using Computers in the Teaching of Writing. Upper Montclair, NJ: Boynton \& Cook Publishers.

Daiute, C. (1981) Psycholinguistic foundations of the writing process. Research in the Teaching of English 15, 5-22.

=(1982) Word processing: Can it make even good writers better? Electronic Learning March/April, 29-31.

-(1983) The computer as stylus and audience. College Composition and Communication 34, 134-45.

-(1984) Performance limits on writers. In R. Beach and L. Bridwell (eds) New Directions in Composition Research (pp. 205-24). New York: Guilford Press.

-(1985) Writing and Computers. Addison Wesley Publishing Company.

-(1986) Physical and cognitive factors in revising: Insights from studies with computers. Research in the Teaching of English May, 141-59.

-(1989) Play as thought: Thinking strategies of young writers. Harvard Educational Review 59(1), 1-23.

Dalton, D. W. and Hannafin, M. (1987) The effects of word processing on written composition. Journal of Educational Research 80(6), 338-42.

Faigley, L. and Witte, S. P. (1981) Analyzing revision. College Composition and Communication 32, 400-14.

(1984) Measuring the effects of revisions on text structure. In R. Beach and L. S. Bridwell (eds) New Directions in Composition Research (pp. 95-108): New York, NJ: The Guilford Press.

Fayol, M. and Gombert, J. E. (1987) Le retour de l'auteur sur son texte: Bilan provisoire des recherches psycholinguistiques. Repères 73, 85-95.

Fitzgerald, J. (1987) Research on revision in writing. Review of Educational Research 57(4), 481-506.

Flower, L. and Hayes, J. R. (1981) A cognitive process theory of writing. College Composition and Communication 32, 365-87.

Flower, L., Hayes, J. R., Carey, L., Schriver, K. and Stratman, J. (1986) Detection, diagnosis, and the strategies of revision. College Composition and Communication 37, $16-55$. 
Frase, L. T. (1984) Knowledge, information, and action: Requirements for automated writing instruction. Journal of Computer-Based Instruction 11(2), 55-9.

Frase, L. T., Kiefer, K. E., Smith, C. R. and Fox, M. L. (1985) In S. W. Freedman (ed.) Theory and Practice in Computer-Aided Composition (pp. 195-211). Norwood, NJ: Ablex.

Frederiksen, C. H. and Dominic, J. F. (1981) Introduction: Perspectives on the activity of writing. In C. H. Federiksen and J. F. Dominic (eds) Writing: The Nature, Development and Teaching of Written Communication. Hillsdale: Erlbaum.

Freedman, A., Clarke, L., Carey, J., De Paul, S. and Miller, A. (1988) The Effect of Computer Technology on Composing Processes and Written Products of Grade 8 and Grade 12 Students. Toronto: Queen's Printer of Ontario.

Friedman, M. P. (1987) WANDAH - A computerized writer's aid. In D. E. Berger, K. Pezdek, and W. P. Banks (eds) Applications of Cognitive Psychology: Problem Solving, Education, and Computing (pp. 219-26). Hillsdale, NJ: Lawrence Erlbaum.

Gould, J. and Grischkowsky, N. (1984) Doing the same work with hard copy and CRT terminals. Human Factors 26, 323-37.

Gould, J. D. (1981) Composing letters with computer-based text editors. Human Factors 23, (323-37).

Guercin F., Roussey, J. Y. and Piolat, A. (1990) Time series: A tool for analyzing complex cognitive activities. Application to the study of text revising strategies. Cahiers de Psychologie Cognitive/European Bulletin of Cognitive Psychology 1, 79-110.

Haas, C. and Hayes, J. R. (1986) What did I just say? Reading problems in writing with the machine. Research in, the Teaching of English 20, 22-35.

Hague, S. A. and Mason, G. E. (1986) Using the computer's readability measure to teach students to revise their writing. Journal of Reading October, 14-17.

Haller, R., Mustchler, H. and Voss, M. (1985) Comparison of input devices for correction of typing errors in office systems. In B. Shakel (ed.) INTERACT '84: First Conference on Human-Computer Interaction (pp. 177-82). Amsterdam, North-Holland: Elsevier Science Publishers B.V.

Halpern, J. W. and Liggett, S. (1984) Computers and Composing: How the New Technologies Are Changing Writing. Carbondale and Edwardsville: Southern Illinois University Press.

Harris, J. (1985) Student writers and word processing: A preliminary evaluation. College Composition and Communication 36, 323-30.

Hawisher, G. E. (1986) The Effects of Word Processing on the Revision Strategies of College Students. Paper presented at the annual meeting of the American Educational Research Association, San Francisco, California, April.

-(1987) The effects of word processing on the revision strategies of college freshmen. Research in the Teaching of English 21(2), 145-59.

Hayes, J. R., Flower, L. S., Schriver, K., Stratman, J. and Carey, L. (1987) Cognitive processes in revision. In S. Rosenberg (ed.) Reading, Writing, and Language Learning (Advances in Applied Psycholinguistics, Vol. II (pp. 176-240)). Cambridge: England, Cambridge University Press.

Hennings, D. (1981) Input: Enter the word processing computer. Language Arts 58, 18-22.

Hilligos, S. (1983) The history of composing tools and the future of word processing. In S. Burton (ed.) Sixth International Conference on Computers and the Humanities (273-80). Rockville ND.

Hull, G. A. and Smith, W. L., (1985) Error correction and computing. In J. L. Collins and E. A. Sommers (eds) Writing On Line: Using Computers in the Teaching of Writing (pp. 89-101). Upper Montclair, NJ: Boyton \& Cook Publishers.

Hult, C. $(1,985)$ The effects of word processing on the correctness of student writing. Research in Wordprocessing Newsletter 3(8), 1-5.

Humes, A. (1983) Research on the composing process. Review of Educational Research 53 (2), 201-216. 
Hunter, L. (1983) Basic writers and the computer. Focus: Teaching English Language Art 9(3), $22-7$.

Joram, E. (1986). The Effects of Editing on Creativity in the Writing Process. Unpublished master's thesis, University of Toronto.

Joram, E., Woodruff, E., Bryson, M. and Lindsay, P. (in press) The effects of revising with a word processor on written composition. Research in the Teaching of English.

Joram, E., Woodruff, E., Lindsay, P. and Bryson, M. (1989) An assessment of students' editing skills and attitudes toward word processors. Submitted to Computers and Composition.

Kleiman, G. and Humphrey, M. (1982) Word processing in the classroom. Compute 22, March, 96-9.

Kozma, R. B. (1989) The impact of computer-based tools and rhetorical prompts on writing processes and products of novice and advanced college writers. Paper presented at the annual meeting of the American Educational Research Association, San Francisco, California, March.

Kurth, R. J. (1987) Using word processing to enhance strategies during student writing activities. Educational Technology January, 13-19.

Later, S., Braganca, R. and Rukavina, I. (1987) Writing with Microcomputers in the Elementary Grades: Process, Roles, Attitudes, and Products. Toronto: Queens Printer for Ontario.

Lindemann, S. and Willert, J. (1985) Word processing in high school writing classes. In J. L. Collins and E. A. Sommers (eds.) Writing On-Line: Using Computers in the Teaching of Writing (pp. 47-53). Upper Montclair, NJ: Boynton \& Cook Publishers.

Loheyde, K. M. (1984) Computer use in the teaching of composition: Considerations for teachers of writing. Computers in the Schools 1(2), 81-6.

Lutz, J. A. (1987) A study of professional and experienced writers revising and editing at the computer and with pen and paper. Research in the Teaching of English 21(4), 398-421.

McClurg, P. A. and Kasakow, N. (1989) Wordprocessors, spelling checkers, and drill and practice programs: Effective tools for spelling instruction? Journal of Educational Computing Research 5(2), 187-9.

McKenzie, J. (1984) Accordion writing-expository composition with the word processor. English Journal 73, 56-8.

Meyers, P. and Tilly, G. A. (1986) Research Project in Word Processing and Writing. Paper presented at the Conference on College Composition and Communication, New Orleans, Los Angeles.

Molitor, S. (1989) Developing and manipulating knowledge by writing. In P. Boscolo (ed.) Writing: Trends in European Research (pp. 160-71). Padova: UPSEL Editore.

Monahan, B. (1982) Computing and revising. English Journal 71, 93-4.

Moran, C. (1983) Word processing and the teaching of writing. English Journal 72 , 113-115.

Morocco, C. C. and Neuman, S. B. (1986) Word processors and the acquisition of writing strategies. Journal of Learning Disabilities 19(4), 243-7.

Morton, L. L., Lindsay, P. H. and Roche, W. M. (1989) Word processing effects on writing productivity and revision at elementary junior high school levels. The Alberta Journal of Educational Research 35(2), 145-63.

Neuman, J. (1984) Online: Reading, writing and computers. Language Arts 61, 758-63.

Nold, E. W. (1981) Revising. In C. H. Frederiksen and J. F. Domonic (eds) Writing: Process, Development and Communication. Hillsdale, NJ: Lawrence Erlbaum.

Odell, L. and Goswani, D. (1985) Writing in Non-academic Settings. New York, NJ: The Guilford Press.

Papert, S. (1980) Mindstorms: Children, Computers and Powerful Ideas. New York, NJ: Basic Books.

Pavard, B. (1985) La conception de systèmes de traitement de Texte. In A. Borillo, J. M. Hoc and M. Quéré (eds.) Intellectica 1(t), 37-67. 
Pearson, H. and Wilkinson, A. (1986). The use of the word processor in assisting children's writing development. Educational Review 38(2), 169-87.

Piolat, A. and Blaye, A. (1991) Effects of word processing and writing aids on revision processes. In M. Carretero, M. Pope, R. Simons and J. Pozo (eds) Learning and Instruction. European Research in an International Context: Vol. III (pp. 379-99): Oxford: Pergamon Press.

Piolat, A. and Roussey, J. Y. (1991) Narrative and descriptive text revising strategies and procedures. European Journal of Psychology of Education 5(2), 155-63.

- (in press) A propos de l'expression 'stratégie de révision' de textes en psychologie cognitive. Textes en main.

Piolat, A. (1988) Le retour sur le texte dans l'activité rédactionnelle précoce. European Journal of Psychology of Education 3(6), 449-59.

-(1990) Vers l'amélioration des textes écrits. Dossier d'Habilitation à Diriger des Recherches. Université de Provence: Aix-en-Provence.

Piper, K. (1983) Evaluating word processing programs for language arts instruction. Computers, Reading, and Language Arts 1, 9-14.

Pontecorvo; C. and Paoletti, G. (1989) Story completion and metalinguistic skills in children working with computer software. In P. Boscolo (ed.) Writing: Trends in European Research (160-71). Padova: UPSEL Editore.

Pyrite, J. (1988) Conceptual models and task representation in using a command language. The Quarterly Journal of Experimental Psychology 40A(3), 443-67.

Rodrigues, D. (1985) Computers and basic writers. College Composition and Communication 36(3), 336-9.

Ross, D. and Bridwell, L. (4984) Integrating computers into a writing curriculum: Or, buying, begging, and building. In W. Wresch (ed.) The Computer in Composition Instruction: A Writer's Tool (pp. 107-119). Urbana, Illinois: National Council of Teachers of English.

Roussey, J. Y. (1991) Text schemas in a modeling paradigm: Improvement of a narrative and a description by ten-year-olds. European Journal of Psychology of Education 5(2), 233-42.

Roussey, J. Y., Piolat, A. and Guercin, F., (1989) Revising strategies for different text types. Language and Education 3(2), 1-15.

Scardamalia, M. and Bereiter, C. (1983) The development of evaluative, diagnostic, and remedial capabilities in children composing. In M. Martlew (ed.) The Psychology of Written Language: A Developmental Approach (pp. 67-95). New York, NJ: John Wiley and Sons.

-(1985) Fostering the development of self-regulation in children's knowledge processing. In S. F. Chipman, J. W. Segal and R. Glaser (eds) Thinking and Learning Skills. Research and Open Questions (pp. 563-77). Hillsdale, NJ: L.E.A.

-(1987) Knowledge telling and knowledge transforming in written composition. In S. Rosenberg (ed.) Reading, Writing and Language Learning Advances in Applied Psycholinguistics, Vol. 2 (pp. 142-75). Cambridge: Cambridge University Press.

Schwartz, H. (1984) Teaching writing with computer aids. College English 46, 239-47.

Schwartz, M. (1982) Computer and the teaching of writing. Educational Technology 22, 27-9.

Selfe, C. L. (1985) The electronic pen: Computers and the composing process. In J. L. Collins and E. A. Sommers (eds) Writing On-Line: Using Computers in the Teaching of Writing (pp. 55-66). Upper Montclair, NJ: Boynton \& Cook Publishers.

Sharples, M and O'Malley, C. (1989) A framework for the design of a writer's assistant. In C. Chapman and W. Hall (eds) A rtificial Intelligence and Human Learning: Intelligent Computer-Aided Instructions (pp. 276-90). Bristol: Arrowsmith Ltd.

Shostak, R. (1982) Computers-assisted composition instruction: The state of the art. In J. Lawlor (ed.) Computers in Composition Instruction (pp. 11-15). Los Alamitos, CA: SWRL Educational Research and Development.

Sommers, E. A. (1985) Integrating composing and computing. In J. L. Collins and E. A. 
Sommers (eds) Writing On-Line: Using Computers in the Teaching of Writing (pp. 3-10). Upper Montclair, NJ: Boynton \& Cook Publishers.

Sommers, N. (1980) Revision strategies of student writers and experienced writers. College Composition and Communication 31, 378-87.

Strickland, J. (1985) Prewriting and computing. In J. L. Collins and E. A. Sommers (eds) Writing On-Line: Using Computers in the Teaching of Writing (pp. 67-82). Upper Montclair, NJ: Boynton \& Cook Publishers.

Suhol, R. A. (1985) Applied word processing: Notes on authority, responsibility, and revision in a workshop model. College Composition and Communication 36, 323-35.

Teles, L. (in press) The adoption of word processing by graduate students in education. Education and Computing.

Watt, D. (1983) Word processor and writing. Independent School 42, 41-3.

Whitney, M. M. (1983) The computer and writing. English Journal 72, 24-31.

Witte, S. P. (1985) Revising, composing theory, and research design. In S. W. Freedman (ed.) The Acquisition of Written Language: Response and Revision (pp. 250-284). Norwood, NJ: Ablex.

Womble, G. G. (1984) Process and processor: Is there room for a machine in the English classroom? English Journal 73, 34-7.

Woodruff, E., Bereiter, C. and Scardamalia, M. (1981-82) On the road to computer assisted composition. Journal of Educational Systems 10, 133-48.

Woodruff, E., Lindsay, P., Bryson, M. and Joram, E. (1986) Some cognitive effects of word processors on enriched and average 8th grade writers. Paper presented at the Annual Meeting of the American Educational Research Association. San Francisco, CA, April.

Wresch, W. (1984) The computer in composition instruction. Paper presented at the National Council of Teachers of English. Urbana, Illinois.

Zinsser, W. (1983) Writing with a Word Processor. New York: Harper Colophon. 